\title{
Water and Irrigation Management in Arid and Semiarid Zones
}

\author{
José Roldán-Cañas * (D) and María Fátima Moreno-Pérez $\mathbb{D}$ \\ Department of Agronomy, Campus de Rabanales, University of Córdoba, 14071 Córdoba, Spain; mfatima@uco.es \\ * Correspondence: jroldan@uco.es
}

Citation: Roldán-Cañas, J.;

Moreno-Pérez, M.F. Water and

Irrigation Management in Arid and

Semiarid Zones. Water 2021, 13, 2446.

https://doi.org/10.3390/w13172446

Received: 31 August 2021

Accepted: 2 September 2021

Published: 6 September 2021

Publisher's Note: MDPI stays neutral with regard to jurisdictional claims in published maps and institutional affiliations.

Copyright: (c) 2021 by the authors. Licensee MDPI, Basel, Switzerland. This article is an open access article distributed under the terms and conditions of the Creative Commons Attribution (CC BY) license (https:// creativecommons.org/licenses/by/ $4.0 /)$.
As we wrote in the summary of this special issue, the purpose of this Special Issue is to report, in more detail, research of water resources management in the frame of sustainable development.

The 2030 Agenda for Sustainable Development is made up of 17 goals and was approved by the United Nations General Assembly in 2015 with the idea that they would be achieved by 2030 [1]. The goal that most affects us in this case is Goal 6 "Clean Water and Sanitation" which involves "Ensure availability and sustainable management of water and sanitation for all". Even though the targets under this goal are aimed more at achieving universal access to drinking water and sanitation and hygiene, it should not be forgotten that in arid and semi-arid areas water resources are very limited and compete with other water uses such as irrigation.

Water use has been increasing by $1 \%$ per year worldwide since the 1980s. Global water demand is expected to continue to increase at a similar rate until 2050, representing an increase of $20-30 \%$ above the current level of water use [2]. Agriculture is by far the largest consumer of water, accounting for $69 \%$ of annual global water withdrawals. Industry accounts for $19 \%$ and households for $12 \%$ [3].

On the one hand, water resources are under great pressure due to the growing demand for more and better quality water. Increasing difficulties in securing water demands have led to increased competition for scarce water resources among traditional water user sectors, i.e., agriculture, industry and urban supply [4].

On the other hand, given the increasing scarcity of water resources, economic concepts such as the marginal cost of water will have to be taken into account in the future when deciding on its use. It is clear, therefore, that only those irrigations capable of producing high added value will be able to compete with other water uses.

Levels of physical water stress are likely to increase as populations and their demand for water grow, and as the effects of climate change intensify. Similarly, climate change and increasing climate variability are likely to oscillate at local and basin scales as well as seasonally. For the most part, however, dry areas will tend to become drier and wet areas wetter, so climate change is likely to exacerbate water stress in areas that are already among the most affected [2].

Non-traditional procedures to increase the supply of water resources include conjunctive use of surface and groundwater [5,6]; reuse of treated wastewater [7] and rainwater harvesting [8]. To reduce demand, productivity and water use efficiency must be increased $[7,9]$. Attempts to adapt farmers' water demands to actual crop demands could lead to a more efficient use of water, as it would allow supplying it only when needed without reducing crop productivity [4].

The situation is especially critical in coastal areas, where most of the available resources come from groundwater [6]. In semi-arid regions, groundwater resources play a crucial role in all economic, environmental and social processes [5]. In these regions, the role of groundwater in agriculture is often underestimated, and economic competition for groundwater from other sectors, particularly industry and urban supply, is affecting adjoining rural areas, where farmers depend on access to groundwater to buffer prolonged periods of drought [10]. 
Groundwater management and its conjunctive use with surface water is critical in arid and semi-arid areas. One of the ways to promote this conjunctive use is by recharging aquifers in times of abundant surface water. Ahmed et al. [5] evaluate the potential of various zones in order to determine those with the best conditions to achieve the most effective recharge.

The authors consider the significance of applying three decision-making approaches: multi-influencing factor, analytical hierarchy process and frequency ratio techniques, to identify potential groundwater zones, and a total of seven criteria (lithology, slope, soil texture, land use, precipitation, drainage density and lineament density) were integrated into a Geographic Information System (GIS) to generate potential recharge zones.

As a result, the map produced using the frequency ratio model was the most efficient $(84 \%)$, followed by the multi-influencing factor model $(70 \%)$ and then the analytical hierarchy process technique $(62 \%)$.

These maps obtained are also useful to select the best locations to drill wells according to the demand.

This aspect of aquifer recharge is also one of the solutions proposed by Pulido-Bosch et al. [6] to achieve sustainable groundwater development in semi-arid regions. Currently, the aquifer they work with, located in south-eastern Spain, is overexploited as a result of the continuous growth of the agricultural sector and a flourishing tourism. They also propose other infrastructure works such as dams or ditches.

However, in this case of a coastal aquifer, desalination would help to solve water deficits before inter-basin transfers, generating more tangible benefits.

In any case, a sustainable water policy requires promoting water saving, reuse and awareness among all water users.

In more extreme climate situations, such as those proposed by Tamagnone et al. [8] in the Sahel, other solutions to the problem of water scarcity must be sought. Indeed, the sub-Saharan climate is suffering an increase in temperature and an intensification of the intensity of precipitation and its variability leading to longer periods of drought. The authors propose in this case a return local-developed techniques rather than advanced "high-tech" solutions.

Specifically, they show that indigenous rainwater harvesting techniques improve runoff retention and double infiltration by increasing the water content in the zone explored by the roots so that the growing season can be extended by up to 20 days by mitigating soil water stress.

Even though the techniques analyzed are those used by the Sahelian population, the procedures used to investigate their hydrological behavior have been advanced numerical models at field scale. Thus, the methodology developed in this article could be extrapolated to other water-scarce areas for better irrigation planning to avoid water stress. In any case, it is necessary to be aware of the scarcity of climatic data available in these areas. Under these conditions the use of complex equations to calculate certain variables, such as evapotranspiration, is somewhat limited. However, a greater availability of data would allow us to consider expressions with more physical meaning in the model developed.

There are semi-arid climate zones where the availability of water has allowed the development of a very productive greenhouse horticulture. This is the case of south-eastern Spain [6] where, however, the pressure on groundwater resources is unbearable. Under these conditions, works such as those of Contreras et al. [7] are fundamental to study how irrigation distribution uniformity affects productivity and water use efficiency in irrigation.

However, in addition, these authors analyze such uniformity in commercial farms considering different water qualities, groundwater versus treated wastewater, and different production systems, conventional versus organic. The results show that the average uniformity in greenhouses using groundwater is higher than those using treated wastewater, although the biggest difference, almost double, is found between those using a conventional production system and those using organic production. 
The cause of lower uniformity when using treated wastewater is due to the higher clogging of drip irrigation emitters given their higher concentration of suspended solids. In the case of the production system, the differences in uniformity are due to the fact that organic fertigation is less soluble.

This also means that the height of infiltrated water shows greater variability when treated wastewater is used or when the production system is organic.

Among the factors conditioning production in these greenhouses are the method of irrigation, drip irrigation as just mentioned and the availability and quality of irrigation water. However, the most important agricultural technique has been the use of sand covers to improve soil humidity and temperature by preventing evaporation from the soil surface and the capillary rise of salts [9]. Specifically, the formation of sanded (enarenado) soils consists of a technique that superimposes on the original soil a soil layer of clayey material, a narrow layer of organic matter and, on top, a layer of sand.

However, the problem that arises is to determine the development of the wet bulb under these conditions since it is a point source of water, the dripper, which produces a three-dimensional infiltration in a stratified soil.

Zapata-Sierra et al. [9] present in this article the appropriate methodology to acquire data to calibrate and validate the Hydrus 3D model. In this way, they calculate the moisture evolution in wet bulbs generated in sanded soils under drip irrigation and with a very common pepper crop in the area and demonstrate that the Hydrus 3D model can reproduce the behavior of water flow in this type of soils. The Hydrus 3D model could, therefore, be used to establish future irrigation strategies or to locate the optimal location of the tensiometers that control irrigation.

In conclusion, the contributions published in this special issue focus on the need for sustainable water and irrigation management in arid and semi-arid areas given the scarcity of water resources and the competition for water among the different waterdemanding sectors.

In terms of water resources, groundwater resources deserve special attention given the scarcity of precipitation that can generate abundant surface flows. In these areas, the conjunctive use of surface and groundwater resources is of great importance since the latter are less subject to the increasingly frequent and more intense climatic variability.

Indigenous water management techniques are also of great interest, as opposed to much more sophisticated and advanced techniques, given their adaptation to their natural environment.

In relation to demand management, it is necessary to improve productivity and efficiency in the use of irrigation water, for which uniformity of distribution is of great importance. The latter is highly conditioned by the quality of the irrigation water used.

The distribution uniformity of irrigation water on the soil surface can be affected once the water infiltrates with the soil playing a fundamental role. This is especially true when the soil is stratified, as is the case of the sanded soils of the greenhouses in southeastern Spain.

Finally, irrigation must be sustainable in relation to its environment, mainly soil and water. Researchers in crop water requirements and in the automation and modeling of irrigation water distribution and application should guide the sustainable management, the good management, of this scarce resource.

Funding: Our time for working on this Special Issue was supported by INIA (Instituto Nacional de Investigación y Tecnología Agraria y Alimentaria), Proyect RTA2015-00029-C02-02; the University of Córdoba; and Spanish Ministry of Science and Innovation, the Spanish State Research Agency, through the Severo Ochoa and María de Maeztu Program for Centers and Units of Excellence in R\&D (Ref. CEX2019-000968-M).

Institutional Review Board Statement: Not applicable.

Informed Consent Statement: Not applicable. 
Acknowledgments: We would like to express our gratitude to all the authors and reviewers of the submissions included in the Special Issue, to the editors of Water Journal and to the staff.

Conflicts of Interest: The authors declare no conflict of interest.

\section{References}

1. U.N. Desa. Transforming Our World: The 2030 Agenda for Sustainable Development; UN DESA: New York, NY, USA, 2015.

2. WWAP (UNESCO World Water Assessment Programme). World Water Development Report 2019: Leaving No One Behind; WWAP: Paris, France, 2019.

3. AQUASTAT-FAO's Global Information System on Water and Agriculture. Water Use. Available online: www.fao.org/nr/ water/aquastat/water_use/index.stm (accessed on 26 August 2021).

4. Moreno-Pérez, M.F.; Roldán-Cañas, J. Assessment of irrigation water management in the Genil-Cabra (Córdoba, Spain) irrigation district using irrigation indicators. Agric. Water Manag. 2013, 120, 98-106. [CrossRef]

5. Ahmed, A.; Ranasinghe-Arachchilage, C.; Alrajhi, A.; Hewa, G. Comparison of Multicriteria Decision-Making Techniques for Groundwater Recharge Potential Zonation: Case Study of the Willochra Basin, South Australia. Water 2021, 13, 525. [CrossRef]

6. Pulido-Bosch, A.; Vallejos, A.; Sola, F.; Molina, L. Groundwater Sustainability Strategies in the Sierra de Gador-Campo de Dalias System, Southeast Spain. Water 2020, 12, 3262. [CrossRef]

7. Contreras, J.I.; Roldán-Cañas, J.; Moreno-Pérez, M.F.; Gavilán, P.; Lozano, D.; Baeza, R. Distribution Uniformity in Intensive Horticultural Systems of Almería and Influence of the Production System and Water Quality. Water 2021, 13, 233. [CrossRef]

8. Tamagnone, P.; Cea, L.; Comino, E.; Rosso, M. Rainwater Harvesting Techniques to Face Water Scarcity in African Drylands: Hydrological Efficiency Assessment. Water 2020, 12, 2646. [CrossRef]

9. Zapata-Sierra, A.J.; Roldán-Cañas, J.; Reyes-Requena, R.; Moreno-Pérez, M.F. Study of the Wet Bulb in Stratified Soils (SandCovered Soil) in Intensive Greenhouse Agriculture under Drip Irrigation by Calibrating the Hydrus-3D Model. Water 2021, 13, 600. [CrossRef]

10. UNESCO, UN-Water. United Nations World Water Development Report 2020: Water and Climate Change; UNESCO: Paris, France, 2020. 